\title{
Outsourcing as a Leveraging Strategy for Organizational Productivity in Covid-19 Era
}

\author{
AUSTIN-EGOLE, Ifeyinwa Stella* IHERIOHANMA, E. B. J. \\ Federal University of Technology, Owerri.
}

\begin{abstract}
The year 2020 was notably one of the most very challenging years in recent times, with the whole world responding and looking to recover from the health and economic challenges posed by the Covid-19 pandemic which impacted hard on every sphere of life. Considering the ferocity of global competition, most businesses have been caught up in revising many operational matters and strategies so as to be able to manage the effects of the pandemic. This they have done by striving to take advantage of areas that they can exploit for improved efficiency as well as reduce costs in order to avail more time for activities that generate revenue. This paper, which adopted analytical discussion of secondary data and anchored on transactional cost economics as its theoretical framework, evaluated the efficacy of outsourcing as a management and production strategy which not only helps companies to overcome productivity challenges by providing unlimited opportunities in this Covid-19 era but equally helps them streamline operations by adding additional resources and value that may have been lacking in-house. This, most business organizations did by re-adjusting and appraising their production and management strategies with regards to their opportunities and strengths; and relinquishing by contracting those activities that challenged their competencies to other third-party professional organizations that performed their hitherto in-house activities for them. It is recommended that in current times, going for an outsourcing partner may be the best thing an organization can do to retain optimal productivity.
\end{abstract}

Keywords: Outsourcing, Covid-19, Transaction cost economics, Pandemic

DOI: $10.7176 / \mathrm{EJBM} / 13-6-14$

Publication date:March $31^{\text {st }} 2021$

\section{Introduction}

It is a known fact that the rapid outbreak of Covid-19 across the world has had an excruciating and extensive impact on the economy and overall business environment. Although some of these impacts are temporary, others appear to have long-term implications. Businesses today are challenged by rapidly evolving scenarios of regulatory changes and continuous advancements in technology. These challenges are causing businesses to rethink the most effective mix of in-house and external resources required to efficiently manage highly important operational processes with flexibility, visibility, transparency, and control (Austin-Egole and Iheriohanma, 2020). This is where the exigency of outsourcing some organization's operations can prove critical to the success of business. According to Troacă and Bodislav (2012), the term "outsourcing" comes from the American terminology "outside resourcing", which means to get resources from the outside. Momme (2002) defines outsourcing as the process of initiating and managing a contractual relationship with an external agent for the provision of services that have formerly been provided in-house. Organizations usually outsource those operations that are resource intensive, meaning that they normally have high labour or capital costs, require specialist competencies, are dependent on or are influenced by the rapidly changing technology and equally require expensive investment (Kamanga \& Ismail, 2016).

Žitkienè and Dudè (2018) opine that both environmental changes that are independent from the organization and internal decisions related to the activity of the organization and its improvement affect the process of outsourcing. The covid-19 pandemic has resulted in unprecedented environmental changes and challenges, and just as we expect that the COVID-19 threat will eventually fade, like the Zika, Ebola, and Severe Acute Respiratory Syndrome (SARS) viruses of yester years, it is pertinent to note that the socio-economic impact will still be felt even after the virus is controlled.

This research therefore, seeks to elucidate on: 1 . The reasons why organizations need to outsource some of their tasks. 2. The numerous advantages organizations stand to gain by outsourcing some of these tasks during this period of covid-19 pandemic.

The methodology adopted in this investigation is library research that is anchored on analytical discussion. Materials from journals, textbooks, etc. were analysed thematically in content form in line with the objectives of the study. This method is adopted as it is germane for an evaluative and discursive investigation of this type in the social and management sciences (Oke and Ibrahim, 2020).

\subsection{Covid - 19 in Brief}

Corona viruses are large group of viruses consisting of genetic materials surrounded by lipid envelop with protein spikes. This gives it the appearance of a crown. Crown in Latin means corona that is where the virus gets its name. 
There are different types of corona virus that cause illnesses in humans and animals. In humans, corona viruses can cause respiratory diseases ranging from common cold to severe diseases. There are different types of corona virus such as SARS-COV (severe acute respiratory syndrome) first identified in China in 2003, MERS-COV (Middle East Respiratory Syndrome) first identified in Saudi Arabia in 2012 and SARS-COV2 the name of the virus that causes Covid-19 discovered in the city of Wuhan, China in December in 2019 (WHO, 2020).

The disease can spread from person to person through droplets when an infected person releases those droplets through coughing, talking or sneezing when close to another person. It can also spread when another person touches the droplets on objects and touches the eyes, nose or mouth. The incubation period which is the time taken from exposure to the virus and development of symptoms is an average of 5-6 days but can range from 1-14 days. There can be a range of symptoms from very mild to severe, some people may be asymptomatic. Common Covid - 19 symptoms include fatigue, fever and respiratory symptoms such as sore throat, cough and shortness of breath. Some people reported cases of loss of taste and smell and some may develop skin rashes. In severe cases, there could be pneumonia or organ failure and death. $80 \%$ of patients recover from it without needing special treatment but there are some groups of people at risk of serious illness. They include older people or people with underlining medical problems such as chronic respiratory diseases, obesity, diabetics, high blood pressure, heart disease or cancer. The virus is normally diagnosed by a test called Reverse Transcriptase- polymer chain reaction generally known as PCR which identifies the virus according to its genetic finger print. There is also the blood test - Serology - that can check for antibodies against the virus that makes sure that someone was affected in the past (WHO, 2020).

Treatment of Covid-19 is mainly supportive care. The treatment is either pharmaceutical (with drugs and medi-care) or non-pharmaceutical (non-medi-care and social/physical distancing). Medicines and vaccines against the virus are currently under investigation such as the Oxford AstraZeneca Covid-19 vaccine and PFIZER Johnson \& Johnson vaccine that United States of America (USA) Regulators have satisfied it's single-shot as "Safe \& Effective" and 97\% effective (arise.tv, Thursday 25, 2021). To prevent transmission of the virus, one needs the non-pharmaceutical measures involving awareness campaigns, covering the mouth and nose with tissue or reflex elbow while sneezing and throwing the tissue into a closed bin immediately after use, washing the hands regularly with soap and water and use of a 70\% alcohol-based hand rub or sanitizers. Avoid close contact - maintain at least two-meter distance from people. There should be use of appropriate face masks and personal protective equipment (PPE) especially in health settings. People should keep off from crowded places or events. It is necessary to follow all government advice on social and physical distancing (WHO, 2016-2021). Since the inception of the outbreak, over 111.7 million cases have been reported in over 223 countries, with about 2.7 million deaths from the virus as at 25th February, 2021 (WHO 2021; Channels TV News @ 6pm). As at Thursday 25 February, 2021, Nigeria that recorded its first test case on the $27^{\text {th }}$ February, 2020, has recorded 153,842 confirmed cases with 130,818 discharged cases and 1,885 deaths in the 36 states and Federal Capital Territory (FCT) Abuja (Nigeria Centre for Disease Control (NCDC) Covid-19, 2021; Presidential Task Force on Covid-19 (PTF), 2021; www.channelstv.com). Nigeria received its first tranche of 3.92 million (about four (4) million), out of sixteen (16) million doses of Oxford AstraZeneca Covid-19 vaccine from India courtesy of UNICEF on March 2, 2021.

\subsubsection{Covid - 19 and Businesses}

The Covid-19 outbreak presented an alarming health crisis that the world is battling with in addition to significant economic, business and commercial impact that is being felt globally. Just as we know that viruses know no borders, it is expected that the impacts will continue to spread. Measures taken to help curb the spread of the pandemic have led to shifting workplaces, cancelation or adoption/involvement of virtual board meetings and conferences, closure of international borders, markets, Churches, Mosques, schools, total or partial lockdown etc. The consequences have taken the turn of declining revenues and, in some cases, workforce reductions, nonpayment of workers' salaries, non-payment of pensions and gratuity of retired workers and other workers' benefits, stringent measures / policies and abandonment of implementation of social services to the people by government in power, among other effects of varying scale.

The results of a very recent survey conducted by Alexander, Marianne, Zoe, Edward, Michael, and Christopher (2020) on more than 5,800 small businesses between March 28 and April 4, 2020 which explored the effect of coronavirus disease 2019 (COVID-19) on small businesses in the United States suggest that the pandemic had already caused immense displacement amongst small businesses within few weeks after its onset and before government aid was made available through the Coronavirus Aid, Relief, and Economic Security (CARES) Act.

Some notable impacts of Covid-19 on businesses include:

The Covid-19 Pandemic has caused the placement of certain restrictions on the movement of both people and goods across international borders. People and goods are the backbone of all businesses and commerce; and any disruption of flows, even for the shortest period of time will have attendant rapid and severe impact on the overall condition of a business (KPMG, 2020). Businesses are now confronted with or dealing with lost revenues and disrupted supply chains due to China's factory shutdowns, tens of millions of people are remaining in lockdown 
in dozens of cities and other countries extending travel restrictions. For many organizations, effective cash flow management is critical during this period as revenues fall and potentially, debtors delay payments.

Work-from-home (WFH) is the new normal for most organizations (Swati, 2020). The truth is that the days of corporate hallways buzzing with employees are almost gone as most of them are now either working remotely or gravitating towards remote working; Covid-19 world is heavily dependent on remote technologies and have brought in digital transformation far sooner than everyone expected. With staff working from home and business leaders focusing on the survival of the business, organizations may struggle during this time to maintain strong daily oversight of compliance processes and as a result, important deadlines may be missed. Unfortunately, most developing countries in the Third World were taken unawares and are yet grappling with putting in place facilities that support these remote technologies. For instance, Nigeria with over a hundred federal universities could not have these institutions open or be remotely in session because the enabling technology, power and manpower to facilitate virtual learning or e-learning were near absent. Only few private universities could run their businesses within the critical period of lockdown. Even at that, most private universities and students involved in e-learning during the critical period complained of network problems, problem of power and infrastructural facilities, high cost and expensive nature of the project etc.

\section{Outsourcing in Brief}

Espino-Rodríguez and Padrón-Robaina (2006) define outsourcing as that typical strategy that utilizes the advantages of the more advanced but lower-priced resources with enhanced efficiency, and invariably brings strategic advantages to the outsourcing firms. As a result of successful outsourcing experience, the outsourcing organization can enjoy the benefits of enhanced dynamic capabilities, such as market-oriented innovation, agility, strategic flexibility and increased efficiency, thereby creating a path of sustainable competitiveness in a volatile environment (Byungjoo, Joohyun, Joonyoung \& Heesang (2019). Momme (2002) observes that outsourcing involves an organization managing a contractual relationship with an external agent or third party for the provision of services that were hitherto provided in-house. Outsourcing is the practice of contracting out certain in-house activities to external agent so that the agent provides the services cheaper, better and at lesser costs. The essence is to disengage from those services that took more time of the organization so that it can concentrate or focus on the areas of core competences and comparative advantage.

The necessity for outsourcing in organization emanates from the unique characteristics that determine, inter alia, the critical and required managerial practices and strategies that suit its circumstances and need. Advances in technology, the sophistication in business processes, stiff but competitive market drives and options, knowledge and knowledge management explosion (Iheriohanma \& Austin-Egole, 2020), constant and consistent growth and profit motive drive, the need for viable employee satisfaction, human resource management practices that support conducive competitive advantage and environment (Dominguez, 2006; Iheriohanma \& Austin-Egole, 2020; Hamzah, Ibrahim, Mohammad, Amro, Sakher \& Hussein, 2020), and the challenges of pandemics that stringently affect work and employment trends such as the Covid-19 that need to be mitigated to ensure organizations stay afloat and sustainability of production in a competitive economy, and many more are few of the reasons for the adoption of outsourcing in organizations.

From outsourcing, a firm can access a broader range of advanced and specialized technology available to the organization that can provide a more competitive resource base. The aims of outsourcing have progressed from cost efficiency, e.g., in offshore manufacturing, to more strategic issues, such as innovation, flexibility and sustainability by reducing risk in an erratic environment (Pellicelli, 2018). It could be added here that there are elements that interact to provide the competitive resource base. These elements interacting within the system are the people, technology and the structure. These three are influenced by the external social system - the environment.

\subsection{Theoretical Framework: Transaction Cost Economics}

Byungjoo, Joohyun, Joonyoung and Heesang (2019) posit that although the concept of outsourcing has been variously proposed in different contexts, the theoretical bedrock for explaining both outsourcing and building a successful outsourcing relationship is mainly based on the economic perspective of Transaction Cost Economics (TCE). Transaction Cost Economics (TCE) was built from the earlier study of Coase (1937), and has become a predominant theory, explaining outsourcing activities via an interdisciplinary approach that combines economics with organizational theory and contract law (Byungjoo, Joohyun, Joonyoung \& Heesang (2019). With Transaction Cost Economics (TCE), the costs pertaining to economic exchange play a significant role in outsourcing decisions, and the transactions are made through the governance form requesting minimum costs (Vivek, Richey \& Dalela, 2009). The approach gives a definite guideline as to when the organization will perform in-house transaction, and when it will turn to the external sources (Hashai, 2018). Coase (1937) pointed out that TCE is concerned with uncertainty factors in deciding appropriate governance mechanisms that include competitive pricing and the necessity of specialized investments. Cost reduction can be achieved through variable structural mechanisms. TCE posits that managerial decisions should be made to minimize the sum of transaction and production costs 
(Williamson, 2007). The basic proposition of the perspective is that if the transaction costs of contracting out outweighs the production cost advantages, firm managements should choose in-house production, rather than outsourcing and vice versa.

The above template provides guides regarding the propositions for contracting out activities that were hitherto performed in-house and the reasons and benefits therefrom. Transaction costs evaluate the necessities of economic exchange and the strategic outsourcing decisions based on the variable structural mechanisms. The Covid-19 pandemic provided varying challenges and options to management regarding production strategies, manpower development, employee retention, technologies etc. The varying constraints to labour relations, employee performance, employee productivity and other related issues during this pandemic make the application of the transaction costs economics theory applicable to explicating the discussion and analysis in this evaluative investigation.

\subsection{Outsourcing and Covid-19: An Analytical Appraisal}

Today's Chief Executive Officers (CEOs) are faced with overwhelming competing challenges and uncharted waters as they continue to navigate the impacts of the Covid-19 pandemic. These organization leaders are facing the crisis with a spirit of reinvention - accelerating digital transformation, establishing variable cost structures, and implementing agile operations. Outsourcing can help organizations to weather the new normal and uncertain challenges brought about by the pandemic. The uncertain challenges have directed attention of CEOs to the dire consequences of downsizing and rightsizing staff due to stoppages and closure of production outfits and the lockdown that affected economic activities worldwide. Be that as it may, organization managers who projected into the future availed themselves the opportunity of the new normal and technological exploration and initiatives and exploited the positive use of robots, drones and artificial intelligence (AI) in production processes as alternatives to physical presence of employees at workplaces (www.channelstv.com). Oke, Ukwuoma and Ibrahim (2020) and Global Times (2020) report that some technologically advanced economies such as China and USA and even some African countries such as Tunisia have made good use of robots and drones to enforce quarantine, stay at home order, take real time images of persons and detected places worst hit by the virus and used artificial intelligence (AI) to generate information related cases for possible improvements and care. Some organizations and research institutes involved themselves in like processes to gather, deliver and corroborate information to stem the rapid spread of the virus. Essentially, the challenges of the corona virus 2019 pandemic remain and have remained a footstool to initiatives and exploitation in the areas of technology, management, HR and labour relations as well as steered off the strategic needs for outsourcing, exploitation of competencies and comparative advantages in organization.

According to Gregg (2020), the impact of Covid-19 has shown that many workers do not necessarily need to be physically present in the office to work effectively; same applies to outsourced workers. Outsourcing specific tasks, like payroll, HR functions and accounting can go a long way towards helping organizations achieve their set goals, reduce overhead costs and ensure that they and other in-house employees are efficiently spending their time and energy on core competencies while reducing stress for business leaders over employee turnover or potential layoffs.

Accounting and finance firms that offer back office as-a-service and as a norm, employ seasoned experts; they utilize the most up-to-date accounting and financial software and are very knowledgeable in local and federal financial rules and regulations. Bearing in mind that unfortunately for businesses, with Covid-19, uncertainty has become part of the new normal of the business environment, outsourcing both back office and accounting functions help an organization to eliminate some of the uncertainties and the risks that come with it including hiring, turnover, layoffs and re-hiring as well as reduction in payroll costs while adding highly qualified experts with a deep pool of resources. Other firms outside accounting and finance firms are availed the opportunity of adjustments and responses to the new normal through transaction costs (Hashai, 2018) and by implication mitigate the demands of the social environment, technology and structural constraints (Gregg, 2020; Hamzah et al., 2019). This is where the transaction costs economics theory remains apt in this investigation.

Outsourcing also offers financial stability during these challenging times. Working with an outsourced back office partner equates to working within a defined, fixed budget. With this, an organization gets to know exactly what it is. Considering that an organization's outsourcing needs change with the same rapid pace as the environment changes during this pandemic, outsourced back office partner can provide on-demand resources to meet the changing needs. This implies that they can quickly react and adjust to the needs of that precise moment. This argument evaluates research objectives one and two of this study as it narrates both the reasons for outsourcing and the accruing benefits in the project. No organization worth its salt will remain reactive always to speedy innovations and flexibility especially given the uncertainties experienced since this pandemic. Again, the transaction costs economics that directly and indirectly determine productivity of organization unravel the opportunities, not only for the organization but the employees' satisfaction. For instance, Hamzah, et al. (2019) and Pan (2015) opine that not only do employees' satisfaction and commitment benefit organizations, they 
accelerate the economic benefits the more to the extent that they place the organization on the pedestal of competitive advantage. In another instance, it is argued here that the transaction costs direct attention to the policy strategies for Human Resource Management (HRM) practices, and by extension, outsourcing strategies and practices to ensure equitable float in this pandemic. A satisfied workforce boosts performance as employee performance determines employee productivity.

Kikis (2021) avers that with outsourcing, business organizations can create a pool of additional funds; from the elimination of expenses from outsourced activities, thus creating enabling opportunities for growth and innovation. The organization accomplishes this through reduction in expenses that would have been incurred from both hiring and training of new employees and/or the support staff (HR, administration, etc.) and occupancy costs from investment in additional office space and equipment. Having a large pool of outsourced "on-demand" talent means organizations can rapidly scale their workforce without the need to hire additional full-time employees, increase their overheads and their investment in office space and equipment. Using outsourcing creates new opportunities and makes better use of existing talent that helps employers get the most out of their current workforce. This also evaluates the objectives of the study as well as authenticates the application of the transaction costs economics theory in this study.

In addition to saving time and money which usually garner all the attention, outsourcing certain operational functions allows organizations access to the latest technology in use and systems as well as best-practice in certain activities as they concentrate on their core competencies (Austin-Egole \& Iheriohanma, 2020). The Codescrum (2020) has noted that the Covid-19 pandemic has not only challenged outsourcing organizations to strive to be at the forefront of technology but also to be innovative and flexible because the old systems synonymous to UPS backups and poor network connectivity are no longer sufficient in the new normal services and protocols. With the enormous growth projected for technology in the coming years, investing in the latest technology may not be an option for most business organizations because of the quantum amount of money to be invested. Staying up to date with latest technology involves huge amount for investment. Outsourcing will give both the outsourcing and contract organizations access to the latest available technology and therefore allow them to remain competitive and relevant at less cost. Outsourcing creates opportunities for professionalization, skills development and specialization. This happens to be in agreement with the theory of transaction costs economics which postulates that if the transaction costs of working in-house outweighs the production costs of outsourcing, firm managements should choose outsourcing production rather than in-house and vice versa.

\subsection{Conclusion}

With the Covid-19 pandemic, the immediate and long-term benefits of outsourcing businesses have been brought to the forefront. Outsourcing ultimately offers business owners great advantages. The strategy allows organizations to work with a team of skilled professionals without the additional expenses of full-time employees and additional office space and equipment. With a pandemic like Covid-19, uncertainty looms large for everyone. Outsourcing can help organizations to weather the storms of new and uncertain challenges brought about by the pandemic by giving business owners and senior organization management the leverage to give their undivided time, attention and resources to their core competencies and spend their time setting new goals, product diversification and finding ways to achieve them. Pandemic or not, outsourcing always provides organizations with easy access to the best minds in the business. With outsourcing, an organization can opt for the right set of talented professionals according to their unique needs thereby bringing greater flexibility and agility to the table. Therefore, in current times, going for an outsourcing partner may be the best thing an organization can do to be more productive.

\section{Recommendations}

The following are recommended based on the analysis and discussion:

- Outsourcing is recommended for organizations - big or small - because the numerous advantages outweigh any uncanny disadvantage provided the organizations have knowledgeable management and committed workforce. It creates opportunities for product diversification, specialization and skills development among the employees.

- Outsourcing takes care of the new normal experienced since the Covid-19 pandemic. It takes care of the new work trends such as flexi-time, work life balance, telecommuting, Zoom and Cloud meetings and conferencing, working from home etc. It caters for the shortage of office spaces and eliminates the fast spread of the virus.

- The outbreak of the virus has directed attention of policy makers and drivers in our educational system to the need for functional education for our teaming youths. It is no longer tenable to churn out graduates from our institutions of learning, especially the higher institutions, who go about brandishing certificates that cannot fetch them the desired jobs. Education curriculum now should aim at functional education where the graduates are strategically equipped at the onset to create jobs, even while in training without distraction, and add value to the economy. This will eventually boost specialization, professionalization, 
diversification of the economy etc. and eventual economic prosperity through stringent outsourcing protocols and productivity.

\section{References}

Austin-Egole, I. S. and Iheriohanma, E. B. J (2020). Outsourcing and Organizational Performance: A Comparative Analysis of Nigeria Bottling Company Plant and Camela Vegetable Oil Company, Owerri, Imo State, Nigeria, Research on Humanities and Social Sciences, 10(12): 64 - 83. www.iiste.org. DOI: 10.7176/RHSS/10-12-09

Austin-Egole, I. S., Iheriohanma, E. B. J. and Nwokorie, C. (2020). Flexible working arrangements and organizational performance: An overview, IOSR Journal of Humanities and Social Science, IOSR - JHSS, 25(Issue 5 Series 6): 50 59. www.iosrjournals.org

Alexander, W. B., Marianne, B., Zoe C., Edward, L. G., Michael, L., \& Christopher, S. (2020). The impact of COVID-19 on small business outcomes and expectations, Proceedings of the National Academy of Sciences of the United States of America (PNAS), 117(30): 17656-17666; https://doi.org/10.1073/pnas.2006991117 Arise News Network (2021). arise.tv

Byungjoo, P., Joohyun, K., Joonyoung, P. \& Heesang, L. (2019). Outsourcing strategies of established firms and sustainable Ccompetitiveness: Medical Device Firms, Sustainability, 11: 4550; doi:10.3390/su11174550

Channels TV News@6pm (2021).www.channelstv.com

Coase, R.H. (1937). The nature of the firm. Economica, 4:386-405

Codescrum (2020). How Outsourcing is Changing Towards a Post-COVID-19 Scenario in 2020; https://codescrum.medium.com/how-outsourcing-is-changing-towards-a-post-covid-19-scenario-in-2020af7c76254c59 Date accessed, 17 January, 2021.

Espino-Rodríguez, T.F.\& Padrón-Robaina, V. A (2006). Review of outsourcing from the resource-based view of the firm. Int. J. Manag. Rev., 8: 49-70

Gregg, G. (2020). COVID-19 pandemic reinforces benefits of outsourced accounting. Accounting Today https://www.accountingtoday.com/opinion/covid-19-pandemic-reinforces-benefits-of-outsourcedaccounting Date accessed, 17 January, 2021.

Hamzah, E., Ibrahim, H., Mohammad, A., Amro, A., Sakher, A. and Hussein, M. H. I. (2020). Employee satisfaction, human resource management practices and competitive advantage: The case of Northern Cyprus, European Journal of Management and Business Economics, 29(2): 125 - 149.

DOI 10.1108/EJMBE-01-2019-0001. Date accessed, 16 January, 2021.

Hashai, N. (2018) Focusing the high-technology firm: How outsourcing affects technological knowledge exploration. J. Manag., 44: 1736-1765.

Iheriohanma, E. B. J. and Austin-Egole, I. S. (2020). Outsourcing and employment trends: An exploratory discourse, Issues in Business Management and Economics, 8(3): 48 - 56. https://www.journalissues.org/IBME/; https://doi.org/10.15739/IBME.20.005.

Kamanga, F. N. \& Ismail, S. N (2016). Effects of outsourcing on organization performance in manufacturing sector in Kenya: A case of Del Monte Kenya limited; European Journal of Logistics, Purchasing and Supply Chain Management, 4(3):32-58

Kikis, P. (2020). Outsourcing relevancy in a post COVID-19 environment; Deloitte; https://www2.deloitte.com/cy/en/pages/tax/articles/outsourcing_relevancy_post_covid19_environment.html Date accessed, 18 January, 2021.

KPMG (2020). Covid-19 Business implications https://assets.kpmg/content/dam/kpmg/ch/pdf/blc-covid-19business-implications.pdf Date accessed, 18 January, 2021.

Momme. J. (2002). Framework for outsourcing manufacturing: Strategic and operational implications, Computers in Industry, 49: 59-7

Nigeria Centre for Disease Control (NCDC) Covid-19 (2021). Report on Covid-19 cases in Nigeria

Oke, M. and Ibrahim, C. (2020). Improving climate adaptation in Nigeria: Between rainwater harvesting and desalination, African Journal of Social Issues 3(1): 112 - 121. https://ajosing.com

Pan, F. C. (2015). Practical application of importance-performance analysis in determining critical job satisfaction factors of a tourist hotel, Tourism Management, 46:84 - 94, Retrieved from https://doi.org/10.1016/j.tourman.2014.06.004, Date accessed, January 16, 2021.

Pellicelli, M. (2018). Gaining Flexibility and Innovation through Offshore Outsourcing. Sustainability, $10: 1672$.

Presidential Task Force on Covid-19 (PTF) (2021). Report on Covid-19 cases in Nigeria

Swati, T. (2020). Outsourcing IT in the post COVID-19 world, The SHRM South-Asia Blog. https://blog.shrm.org/sasia/blog/outsourcing-it-in-the-post-covid-19-world Date accessed, 16 January, 2021.

Troacă, V.A. \& Bodislav, D.A. (2012). Outsourcing. The Concept. Theor. Appl. Econ., 6:51

Vivek, S.D., Richey, R.G., Jr.\& Dalela, V. A (2009). Longitudinal examination of partnership governance in offshoring: A moving target. J. World Bus. 44: 16-30 
Williamson, O.E. (2007). The economic institutions of capitalism. Firms, markets, relational contracting. In Das Summa Summarum des Management; Springer: Berlin/Heidelberg, Germany, 61-75.

World Health Organization WHO, (2021). Coronavirus disease (COVID-19) pandemic; https://www.who.int/emergencies/diseases/novel-coronavirus-2019 Date accessed, 16 January, 2021.

World Health Organization WHO, (2016-2021). Introduction to COVID-19: methods for detection, prevention, response and control. https://openwho.org/courses/introduction-toncov/items/3E1PsZwgM9k6NS5QfUUH99 Date accessed, 20 ${ }^{\mathrm{TH}}$ January, 2021.

Williamson, O.E. (2007). The economic institutions of capitalism. Firms, markets, relational contracting. In Das Summa Summarum des Management; Springer: Berlin/Heidelberg, Germany, 61-75.

Žitkienė, R. \& Dude,, U. (2018). The impact of outsourcing implementation on service companies. Entrepreneurship and Sustainability Issues, Entrepreneurship and Sustainability Center, 6 (1), 342-355. ff10.9770/jesi.2018.6.1(21)ff. ffhal-02167060f 